\title{
Kahoot! Application in Medical Education: A Fact for Student Motivation Level
}

\author{
Galuh Suryandari ${ }^{1}$, Alfan Al-Ghifari Sudarmanto ${ }^{2}$ \\ Correspondence Author : galuhsuryandari@umy.ac.id \\ ${ }^{1}$ Faculty of Medicine and Health Sciences, Universitas Muhammadiyah Yogyakarta, Indonesia \\ ${ }^{2}$ Faculty of Medicine and Health Sciences, Universitas Muhammadiyah Yogyakarta, Indonesia \\ I N D E X I N G \\ Keywords: \\ Kahoot !; \\ Motivation; \\ Medical education; \\ Lecture; \\ Grade.

\begin{abstract}
A B S T R AC T
An implementation and effort of technology in medical education to increase student motivation of the large-scale classes are increasing worldwide. One of them is Kahoot!. This study has the purpose of measuring student motivation levels in the medical school of FKIK UMY after the implementation of Kahoot!. A quasiexperimental method was implemented in this study. The data was collected using the Motivated Strategies for Learning Questionnaire (MSLQ). During the normality test by using the Kolmogorov Smirnov method, all of the data has the amount of $p>0,05$. Therefore we used non-parametric analysis with independent sample T-test and one way ANOVA to figure out the relation of student grades and students' motivation level. The result of the research shows that students in 2015 grade have lower motivation levels after implementing Kahoot!, The other three grades (2016, 2017, and 2018) have a higher motivation level after implementing Kahoot!.
\end{abstract}

Kata Kunci:

Kahoot!;

Motivation;

Penerapan dan upaya penggunaan teknologi dalam pendidikan kedokteran untuk meningkatkan motivasi siswa pada kelas skala besar semakin meningkat di seluruh dunia. Salah satunya adalah Kahoot!. Penelitian ini bertujuan untuk mengukur tingkat motivasi mahasiswa fakultas kedokteran FKIK UMY pasca implementasi Kahoot! Penelitian ini menggunakan metode eksperimen semu. Data dikumpulkan dengan menggunakan Motivated Strategies for Learning Questionnaire (MSLQ). Uji normalitas dengan menggunakan metode Kolmogorov Smirnov menunjukkan bahwa semua data memiliki nilai $p>0,05$. Dengan demikian, analisis statistic menggunakan nonparametrik dengan independent sample T-test dan one way ANOVA untuk mengetahui hubungan nilai siswa dan tingkat motivasi siswa. Hasil penelitian menunjukkan bahwa mahasiswa angkatan 2015 memiliki tingkat motivasi yang lebih rendah setelah penerapan Kahoot!, tiga kelas lainnya (2016, 2017, dan 2018) memiliki tingkat motivasi yang lebih tinggi setelah penerapan Kahoot!.

(C) 2020 JMMR. All rights reserved

Article History: Received 2020-07-06; Revised 2020-08-06; Accepted 2020-08-27

\section{INTRODUCTION}

An implementation of technology in medical education especially in large-scale class increased. It is caused by the facility which is offered by the technology. There are some facilities which can be gotten by using technology namely ease and practicality. The usage of technology can ease not only the decision (drug reference, medical calculators, etc) but also in searching medical references (Masters et al., 2016). Although technologies have offered several privileges, it still cannot be relied totally (Krishnan et al., 2017). The environment, lecturer, and students should contribute to success the learning process (Arkan et al., 2018). One of the factors which can make learning process successful is students' motivation. Research shows that student motivation and learning strategies could be the trigger to student's learning process (Kim \& Jang, 2015). Meanwhile, learning grade and experiences also plays a factor in student's learning motivation process, therefore it is important to kept it well (Defoe et al., 2015).

Students' motivation becomes one of the factors which can determine whether the learning process is successful or not especially on the student engagement side (Nayir, 2017). 
The most important factor either in large-scale class or teachers' centered learning is not just the material but also students' motivation (Hafez, 2016). Medical education students, especially in large-scale class need high motivation during learning process. To increase students' motivation, lecturer can use many methods. One of the method is using Kahoot!. Kahoot! (http:/getKahoot.com) is a educational game platform which is used by 50 million people from 180 countries. It is easy to use Kahoot! because you only need your own device (Ismail \& Mohammad, 2017).

As reported in large-scale class of The U.S Military Academy at West Point, there were differences before and after Kahoot! implementation. The research was done by giving 123 cadets at The U.S Military Academy at West Point questionnaire before the lesson started (Borrell et al., 2017). 75\% cadets studied harder when they knew there will be a quiz which used Kahoot! It can be a sign that Kahoot! affect students' motivation.

Creating a research about this in medical education is important because as the time passes by, the implementation of technology are getting higher. The future of medical education lies in technology therefore we have to take this thing seriously (Berman et al., 2016). Most of research about Kahoot! implementation only talked about the implementation. There was no research which focuses on each grade. Thus, this study focused on comparison of students' motivation level in each grade before and after Kahoot! implementation at Program Studi Pendidikan Dokter Fakultas Kedokteran dan Ilmu Kesehatan Universitas Muhammadiyah Yogyakarta (PSPD FKIK UMY).

\section{RESEARCH METHOD}

The quantitative method was used in this study with a quasi-experimental design. There's no control class, only pre and post. This treatment was aimed to measure pre and post-intervention (the use of Kahoot!). The data were collected by using a questionnaire. Motivated Strategies for Learning Questionnaire (MSLQ) consisted of 18 questions. It was started from October 2018 to April 2019. The population in this study were students of the Medical Study Program class of 2015, 2016, 2017, and 2018 who participated in a single partner lecturer's lecture process with the application. The samples in this study were students who took part in the lecture process of a single partner lecturer by implementing the application. Inclusion criteria in this study were students who took part in the lecture process of a single partner lecturer by applying the application and were willing to fill out an approval form to fill out the MSLQ online questionnaire. For the exclusion criteria in this study were students who repeated the block, students who failed to log in on the Kahoot! Application, and or did not fill out the consent form to fill out the MSLQ online questionnaire. Based on the inclusion and exclusion criteria, there were 12 students from 2015, 64 students from 2016, 70 students from 2017, and 59 students from 2018.

\section{RESULT AND DISCUSSION}

During the research, we spread the questionnaire before the lecture process and after the lecture process. In this case, the lecturer usually commences Kahoot! quiz at the end of the lecture process. After collecting data using the MSLQ questionnaire, a multivariate data analysis test was performed with an independent sample T-test as follows: 
Table.1 Motivation score on grade 2016, 2017, and 2018 before implementing Kahoot!

\begin{tabular}{|c|c|c|c|}
\hline Grades & Average score & Minimum score & Maximum score \\
\hline 2015 & 95,00 & 72 & 110 \\
\hline 2016 & 97,20 & 72 & 124 \\
\hline 2017 & 92,64 & 57 & 125 \\
\hline 2018 & 97,69 & 46 & 126 \\
\hline
\end{tabular}

From table.1, before the application of the Kahoot Quiz! In the 2015 class, the average score was 95.00, the lowest score was 72, and the highest score was 110 . In the 2016 class, the average score was 97.20, the lowest score was 72, and the highest score was 124. In 2017, the results obtained an average value of 92.64, the lowest score of 57, and the highest value of 125. While for the 2018 class, the average score was 99.15, the lowest score was 46, the middle value was 100, and the highest score was 126.

Table.2 Motivation score on grade 2015,2016, 2017, and 2018 after implementing Kahoot!

\begin{tabular}{|c|c|c|c|}
\hline Grade & Average score & Minimum score & Maximum score \\
\hline 2015 & 91,67 & 73 & 108 \\
\hline 2016 & 107,17 & 85 & 126 \\
\hline 2017 & 104,41 & 72 & 126 \\
\hline 2018 & 101,56 & 72 & 126 \\
\hline
\end{tabular}

Based on the table.2, after the application of the Kahoot! In class 2015, the average score was 91.67, the lowest score was 73, and the highest score was 108. In the 2016 class, the average score was 107.17, the lowest score was 85 , and the highest score was 126 . In 2017, the results obtained an average value of 104.41, the lowest score of 72, and the highest score of 126. Meanwhile, after the application of the Kahoot! In the 2018 class, the average score was 103.22, the lowest score was 72, and the highest score was 126.

Based on the table. 1 and table.2, there was a decrease in learning motivation score in 2015 grade, which have the average of 95,00 in the pretest, decreasing to 91,67 in the post test. This decreasion in line with the decresion of maksimum and minimum score. Meanwhile, in 2016, 2017, and 2018, there were several increases in learning motivation score. In 2016, the increase come from 97,20 during the pretest to 107,17 in the post test. In 2017 grade, the pretest score averagely in 92,64 while the post test is 104,41 , and in 2018 grade, the average score of the pretest is 97,69 and the average score of the post test is 101,56 . This increasion in line with the incresion of maksimum and minimum score. 
Table.3 Analyzation of student's motivation in the grade 2015,2016,2017 and 2018 before and after implementation of the Kahoot Quiz!

\begin{tabular}{|c|c|c|c|}
\hline Grade & Score & Average score & Sig \\
\hline \multirow{2}{*}{2015} & Before & 95,00 & .507 \\
\cline { 2 - 3 } & After & 91,67 & \\
\hline \multirow{2}{*}{2016} & Before & 97,20 & .000 \\
\cline { 2 - 3 } & After & 107,17 & \multirow{2}{*}{.000} \\
\cline { 2 - 3 } & Before & 92,64 & \\
\hline \multirow{2}{*}{2017} & After & 104,41 & \\
\cline { 2 - 3 } & Before & 97,69 & \\
\cline { 2 - 3 } & After & 101,56 & \\
\end{tabular}

Based on the table.3, to figure whether Kahoot! could create effect towards the student learning motivation significantly or not, we used Independent T-test analysis in SPSS. The effect could be considered significant if the $p$ value is less than $0,05(p<0,05)$. It is found that in 2015 batch, the significance value is 0.507 , which means that the decrease of the average score learning motivation is not significant. In the 2016 and 2017 grade, the significance value is 0,000 which means that the average score of learning motivation increase is significant. In the 2018 grade, the significance value is 0,163 , therefore, the increase of average score learning motivation value in 2018 grade is not significant.

Table.4 Effect of the learning period on student motivation

\begin{tabular}{|c|c|c|}
\hline & df & Sig. \\
\hline Between Groups & 3 & .000 \\
\hline Within Groups & 201 & \\
\hline Total & 204 & \\
\hline
\end{tabular}

Based on the table. 4 it can be concluded that there is an increase of score on the fulfillment of questionnaire MSLQ for grades 2016 and 2017. Then, $p$ value is less than $0_{j} .05$ which can be concluded that there is a significant difference before and after implementation of Kahoot! Different from two grades, there is no difference from grades 2015 and 2018 because the $p$ value is more than 0.05. Based on one-way ANOVA, the p value is less than 0.05 so it can be concluded that there is an effect of the learning period with learning motivation

In comparison to the average score of completing the MSLQ questionnaire in the grades of 2015 before and after the implementation of the Kahoot Quiz! Decreased by an insignificant amount. In comparison the average value of completing the MSLQ questionnaire in the 2016 and 2017 grades before and after the Kahoot Quiz application! Experienced a significant increase. In comparison to the average value of completing the MSLQ questionnaire in the class of 2018 before and after the application of the Kahoot Quiz! Insignificant increase.

Based on the correlative test conducted in this study, it was found that there was an increase in student motivation after the Kahoot! On the other hand, on three grades of FKIK UMY students, there was also a decrease in motivation to learn in 1 student learning force after the Kahoot! -.. expected that the results between student scores and student cumulative achievement index could be directly proportional to the increase in motivation after the 
application of the Kahoot! Quiz. In a study, it was found that there was an increase in the student achievement index after the implementation of the Kahoot! in lecture activities. This is consistent with the researchers' estimation, which states that increased motivation in lectures after the Kahoot! will increase the student achievement index (Vranešić et al., 2019). This application is a promissing assessment tool that can makes learning fun and enjoyable so that student can be motivated to learn (Ismail \& Mohammad, 2017). On the other hand, motivation and student learning perception related well to achieve good results during the learning process (Artino et al., 2012).

In terms of interface, and Kahoot quiz mechanism! Itself, the implementation of the Kahoot quiz! It can increase student motivation. Kahoot quiz app interface! It shows the results of the top 5 names or numbers of students with the best value in each question is proven to increase student motivation to get good grades in the application of the Kahoot quiz (Taitano \& Vuong, 2017). This interface system can make students to pay more attention and interact better in each lecture, and it affect good competition between each student (Licorish et al., 2018). Better attention and interaction means greater student engagement during the learning process as well (Correia \& Santos, 2017). For the lecturer, creating new Kahoot! quiz are intuitive and user friendly, therefore it is not hard for them to create the quiz (Wang \& Tahir, 2020). Interactive quiz like this also increasing student's preparation before facing examination, so it is important to them to get a good score during quiz process (Ammar \& Lefebvre, 2019).

In this study it was found that the motivation generated by the implementation of the Kahoot! in the lecture process large classes are a type of extrinsic and intrinsic motivation (Tóth et al., 2019). With information about the ranking of participants who took the Kahoot! Quiz, prizes after winning the quiz, and the atmosphere of intense competition in working on the Kahoot quiz, quiz participants always felt that they wanted to win the Kahoot quiz application! in single class lectures (Bicen \& Kocakoyun, 2017). In terms of the types of extrinsic motivation, the application of the Kahoot! Quiz in large classes can create an atmosphere of competitive competition between students, create a sense of wanting to win and foster the desire of quiz participants to achieve the highest results compared to other participants (Lin \& Kaur, 2018).

In terms of intrinsic motivation that a key element to achieved learning, Kahoot! become one of the stimulants so that students are able to face and control the challenges in lectures. Kahoot motivates them to take up challenges, able to control it, absorb the activity, stimulating their intrinsic interest and they value the session as a useful activity for learning (Ismail \& Mohammad, 2017). Meanwhile, lower intrinsic motivation means lower cognitive process during lecturing process, so it is important to keep student's motivation both intrinsic and extrinsic in proper level in order to make easier process for them to learn (Silva et al., 2018).

In terms of the influence of the learning period on student motivation, this study found a decrease in learning motivation after the application of the Kahoot! Quiz, which is the only result of decreased motivation in this study. This happened because the when the learning period increases, student motivation will gradually decrease (Sturges et al., 2016). This decrease in learning motivation is influenced by various causes such as lack of planning, 
lack of learning objectives, poor learning strategies, and lack of independence in learning (Demirören et al., 2016).

\section{CONCLUSION}

It can be concluded that there is a significant difference for students grades 2016 and 2017. However, for grades 2018 it cannot be found the difference. Grades 2015 can be the special case because the motivations decrease after implementing Kahoot! quiz. This study has some limitations such as sample. For further study, the sample should be larger, while students fulfill the questionnaire there should be control, and also controlling environment while using Kahoot!. Transparency and integrity must be upheld as well during the research in order to avoid any cheating or fraud during the quiz implementation.

\section{REFERENCES}

Ammar, S., \& Lefebvre, S. (2019). Formative evaluation in the service of active learning. 7.

Arkan, B., Ordin, Y., \& Yilmaz, D. (2018). Undergraduate nursing students' experience related to their clinical learning environment and factors affecting to their clinical learning process. Nurse Education in Practice, 29, 127-132. https://doi.org/10.1016/j.nepr.2017.12.005

Artino, A. R., Dong, T., DeZee, K. J., Gilliland, W. R., Waechter, D. M., Cruess, D., \& Durning, S. J. (2012). Achievement Goal Structures and Self-Regulated Learning: Relationships and Changes in Medical School. Academic Medicine, 87(10), 1375-1381. https://doi.org/10.1097/ACM.0b013e3182676b55

Berman, N. B., Durning, S. J., Fischer, M. R., Huwendiek, S., \& Triola, M. M. (2016). The Role for Virtual Patients in the Future of Medical Education: Academic Medicine, 91(9), 1217-1222. https://doi.org/10.1097/ACM.0000000000001146

Bicen, H., \& Kocakoyun, S. (2017). Determination of university students' most preferred mobile application for gamification. World Journal on Educational Technology: Current Issues, 9(1), 18. https://doi.org/10.18844/wjet.v9i1.641

Borrell, J., Cosmas, N., Grymes, J., \& Radunzel, J. (2017). The Effectiveness of Kahoot! As a Prelesson Assessment Tool. The U.S Military Academy at West Point.

Correia, M., \& Santos, R. (2017). Game-based learning: The use of Kahoot in teacher education. 2017 International Symposium on Computers in Education (SIIE), 1-4. https://doi.org/10.1109/SIIE.2017.8259670

Defoe, I. N., Dubas, J. S., Figner, B., \& van Aken, M. A. G. (2015). A meta-analysis on age differences in risky decision making: Adolescents versus children and adults. Psychological Bulletin, 141(1), 48-84. https://doi.org/10.1037/a0038088

Demirören, M., Turan, S., \& Öztuna, D. (2016). Medical Students' Self-Efficacy in ProblemBased Learning and Its Relationship With Self-Regulated Learning. Medical Education Online.

Hafez, S. (2016). The "ABC to H" Rules of Teaching Large Classes in Medical Education: What do students think? MedEdPublish, 5(3). https://doi.org/10.15694/mep.2016.000139

Ismail, M. A.-A., \& Mohammad, J. A.-M. (2017). Kahoot: A promising Tool for Formative Assessment in Medical education. Education in Medicine Journal, 19-26. 
Kim, K.-J., \& Jang, H. W. (2015). Changes in medical students' motivation and self-regulated learning: A preliminary study. International Journal of Medical Education, 6, 213-215. https://doi.org/10.5116/ijme.565e.0f87

Krishnan, K., Thoma, B., Trueger, N. S., Lin, M., \& Chan, T. M. (2017). Gestalt assessment of online educational resources may not be sufficiently reliable and consistent. Perspectives on Medical Education, 6(2), 91-98. https://doi.org/10.1007/s40037-0170343-3

Licorish, S. A., Owen, H. E., Daniel, B., \& George, J. L. (2018). Students' perception of Kahoot!'s influence on teaching and learning. Research and Practice in Technology Enhanced Learning.

Lin, D. T. A., \& Kaur, M. (2018). Kahoot! It: Gamification in Higher Education. 19.

Masters, K., Ellaway, R. H., Topps, D., Archibald, D., \& Hogue, R. J. (2016). Mobile Technologies in Medical Education: AMEE Guide No. 105. Medical Teacher.

Nayir, F. (2017). The Relationship between Student Motivation and Class Engagement Levels. Eurasian Journal of Educational Research, 17(71), 59-78. https://doi.org/10.14689/ejer.2017.71.4

Silva, W. F., Redondo, R. P., \& Cardenas, M. J. (2018). Intrinsic motivation and its association with cognitive, actitudinal and previous knowledge processes in engineering students. Contemporary Engineering Sciences, 11(3), 129-138. https://doi.org/10.12988/ces.2018.79114

Sturges, D., Maurer, T. W., Allen, D., Gatch, D. B., \& Shankar, and P. (2016). Academic performance in human anatomy and physiology classes: A 2-yr study of academic motivation and grade expectation. The American Physiological Society, 26-31.

Taitano, E. J., \& Vuong, K. (2017). ANALYZING THE EFFICACY OF THE TESTING EFFECT USING KAHOOTTM ON STUDENT PERFORMANCE. Turkish Online Journal of Distance Education, 80-80. https://doi.org/10.17718/tojde.306561

Tóth, Á., Lógó, P., \& Lógó, E. (2019). The Effect of the Kahoot Quiz on the Student's Results in the Exam. Periodica Polytechnica Social and Management Sciences, 27(2), 173179. https://doi.org/10.3311/PPso.12464

Vranešić, P., Aleksić-Maslać, K., \& Sinković, B. (2019). Influence of Gamification Reward System on Student Motivation. International Convention on Information and Communication Technology, Electronics and Microelectronics (MIPRO), 886-892.

Wang, A. I., \& Tahir, R. (2020). The effect of using Kahoot! For learning - A literature $\begin{array}{lllll}\text { review. Computers } & \mathcal{E} & \text { Education, } & 103818 .\end{array}$ https://doi.org/10.1016/j.compedu.2020.103818 